"Socially responsible interaction of a business-organization with an internal stakeholder"

\begin{tabular}{|c|c|}
\hline AUTHORS & Olha Dyakiv (D https://orcid.org/0000-0002-3512-1676 \\
\hline ARTICLE INFO & $\begin{array}{l}\text { Olha Dyakiv (2018). Socially responsible interaction of a business-organization } \\
\text { with an internal stakeholder. Social and labour relations: theory and practice, } \\
\text { 8(2), 69-74. doi:10.21511/slrtp.8(2).2018.07 }\end{array}$ \\
\hline DOI & http://dx.doi.org/10.21511/sIrtp.8(2).2018.07 \\
\hline RELEASED ON & Thursday, 14 March 2019 \\
\hline RECEIVED ON & Sunday, 09 December 2018 \\
\hline \multirow[t]{2}{*}{ ACCEPTED ON } & Wednesday, 26 December 2018 \\
\hline & $(\mathrm{cc}) \mathrm{EY}$ \\
\hline LICENSE & $\begin{array}{l}\text { This work is licensed under a Creative Commons Attribution } 4.0 \text { International } \\
\text { License }\end{array}$ \\
\hline JOURNAL & "Social and labour relations: theory and practice" \\
\hline ISSN PRINT & $2410-4752$ \\
\hline ISSN ONLINE & $2415-3389$ \\
\hline PUBLISHER & LLC "Consulting Publishing Company "Business Perspectives" \\
\hline FOUNDER & $\begin{array}{l}\text { State Higher Educational Establishment "Kyiv National Economic University } \\
\text { named after Vadym Hetman", Social and Labour Relations Institute }\end{array}$ \\
\hline & $\begin{array}{l}\text { Z:- } \\
\text { Z:- }\end{array}$ \\
\hline NUMBER OF REFERENCES & NUMBER OF FIGURES \\
\hline 10 & 0 \\
\hline
\end{tabular}

(C) The author(s) 2023. This publication is an open access article. 


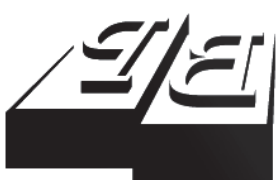

BUSINESS PERSPECTIVES

Publisher:

LLC "CPC "Business Perspectives" Hryhorii Skovoroda lane, 10, Sumy, 40022, Ukraine www.businessperspectives.org

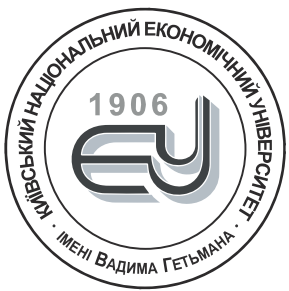

\section{HETMAN KNEU}

Founder:

State Higher Educational Establishment "Kyiv National Economic University named after Vadym Hetman",

Prospect Peremogy, 54/1,

Kyiv, 03057, Ukraine

https://kneu.edu.ua/

Received on: 9th of

December, 2018

Accepted on: 26th of

December, 2018

(C) Olha Dyakiv, 2018

Olha Dyakiv, Ph.D., Assistant Professor of the Department of Human Resource Management and Regional Economics, Ternopil National Economic University, Ukraine.

\section{(c) (i)}

This is an Open Access article, distributed under the terms of the Creative Commons Attribution 4.0 International license, which permit unrestricted re-use, distribution, and reproduction in any medium, provided the original work is properly cited.

\title{
SOCIALLY RESPONSIBLE INTERACTION OF A BUSINESS-ORGANIZATION WITH AN INTERNAL STAKEHOLDER
}

\begin{abstract}
The purpose of the article is to clarify the essence of social responsibility in the field of engagement, interviewing and recruiting. The object is defined by the internal social responsibility of the employer, which covers the processes of hiring and adaptation, motivation, development and evaluation of their own personnel, which is the main stakeholder of the organization.

Modern methods of research, in particular: scientific abstraction (in the study of the essence of categories of corporate social responsibility, a system approach (to justify the principles that influence corporate social responsibility), etc., are used to achieve the stated goal and to solve the above tasks. The provisions and conclusions of the work are a system of measures aimed at ensuring productive employment, a fair compensation policy, creating conditions for the full development of human potential, taking into account the own interests of the main business goals and development strategies of the enterprise.

Principles of employer's social responsibility in compensation policy are revealed. They are: decent wages, social support of employees; catering and payment for employees' medical services; improvement of employees' health; employees' leisure time; employees' health care; assistance in critical situations; financial support; additional medical and social security; positive psychological climate in the team. Components of organization social responsibility in the sphere of professional training are investigated. They are: training and development; forming of employees' individual development plans; selection of employees forms and methods of training; definition of training efficiency indicators; employees' professional mobility; planning and career management; formation of personnel reserve etc. It is established that personnel development includes: training programs, professional development, trainings, internship, corporate universities, grants, research and practical development, innovative employment through the "knowledge economy", favorable conditions for growth of personnel creative potential.
\end{abstract}

\section{Keywords}

JEL Classification

О.П. Дяків (Україна) personnel adaptation, internal social responsibility, compensation policy, recruitment, personnel assessment, personnel development, social responsibility, stakeholders

\section{СОЦІАЛЬНО ВІДПОВІДАЛЬНА ВЗАЄМОДІЯ БІЗНЕС-ОРГАНІЗАЦІї ІЗ ВНУТРІШНІМ СТЕЙКХОЛДЕРОМ}

\section{Анотація}

Метою статті $є$ з'ясування сутності соціальної відповідальності у царині залучення, проведення співбесіди та відбору персоналу. Об'єктом визначено внутрішню соціальну відповідальність роботодавця, яка охоплює процеси найму та адаптації, мотивації, розвитку та оцінювання власного персоналу, як головного стейкхолдера організації.

Для досягнення визначеної мети і вирішення окреслених завдань використано сучасні методи дослідження, зокрема: наукового абстрагування (при вивченні сутності категорій корпоративна соціальна відповідальність; системного підходу (для обгрунтування принципів, що впливають на корпоративну соціальну відповідальність) тощо.

Положення та висновки роботи є системою заходів що спрямовані на забезпечення продуктивної зайнятості, справедливої компенсаційної політики, створення умов для всебічного розвитку людського потенціалу, враховуючи власні інтереси основних бізнес-цілей і стратегій розвитку підприємства.

Розкрито принципи реалізації соціальної відповідальності роботодавців у царині компенсацій- 
ної політики: гідна заробітна плата, соціальна підтримка працівників; організація харчування та оплата медичних послуг працівникам, оздоровлення, дозвілля персоналу; турбота про здоров’я працівників; допомога працівникам у критичних ситуаціях; матеріальна допомога; додаткове медичне й соціальне страхування працівників; хороший психологічний клімат у колективі.

Досліджено складові соціальної відповідальності організації в царині професійної підготовки та підвищення кваліфікації персоналу: навчання та підвищення кваліфікації працівників; розроблення індивідуальних планів розвитку працівників; вибір форм і методів навчання працівників; визначення показників ефективності навчання; службово-професійне переміщення працівників; планування та управління кар'єрою; формуванні кадрового резерву тощо. Встановлено, що розвиток персоналу в організації проходить через програми навчання, підвищення кваліфікації; тренінги, стажування; корпоративні університети; отримання грантів, наукові й практичні розробки; впровадження інноваційної зайнятості через «економіку знань»; сприятливі умови для зростання творчого потенціалу працівників.

\section{Ключові слова адаптація персоналу, внутрішня соціальна відповідальність, компенсаційна політика, найм Класифікація JEL M14, M54 \\ PROBLEM STATEMENT AND ITS CONNECTION WITH IMPORTANT SCIENTIFIC AND PRACTICAL TASKS}

In modern conditions of Ukrainian business, employers emphasize the importance of attention to the internal components of social responsibility because they believe that the staff is an important resource and from its activity depends on its profitability and success of the organization. Relationships between employers, employees and the state are carried out within the social partnership in the form of contracts and agreements. The modern concept of internal social responsibility is in its infancy and needs to be studied by many managers of modern organizations.

\section{LITERATURE REVIEW}

There are a lot of theoretical approaches to the definition and interpretation of "corporate social responsibility", sometimes they contradict to each other and have ambiguous interpretation. The representae tives of scientific school of Kyiv national economic university named after Vadym Hetman, including Kolot, Grinenko, Petyuh, Tsymbaliuk and others: Carroll, Grishnova, Belyayeva, Shastun, which actively work on problematics of corporate social responsibility, are engaged in search of ways to improve the efficiency of this social institution.

\section{DETERMINATION OF THE ISSUES, WHICH ARE NOT RESOLVED IN CHOSEN PROBLEM TO STUDY}

Social responsibility of the employer as a subject of social and labor relations is regarded by the public authorities, trade unions and civil society organizations primarily as the external environment that pays taxes, interacts with the interested parties and others. And social responsibility from the inside mostly is considered as a desire to profit employer. Therefore, the study of the internal environment in social responsibility assumes to provide high staff performance.

\section{THE MAIN MATERIAL OF ARTICLE WITH JUSTIFICATION OF SCIENTIFIC RESULTS}

Category of corporate social responsibility is a phenomenon that is inherent only to a market economy. Carroll proposes to treat corporate social responsibility (hereinafter referred to as "CSR") as a kind of "pyramid" consist- 
ing of economic, legal, ethical and discretionary (philanthropic) responsibilities of the organization before society (Carroll, 1999). According to the definition of Belyaeva (2016), CSR is a direction of business for sustainable development. Scientist Grynenko (2012) asserts “.... the main element of the notion of corporate social responsibility is the conscious, voluntary nature of socially responsible activity. The organization voluntarily undertakes to implement measures aimed at improving the situation in areas not directly related to its commercial activities".

The author (Dyakiv, \& Demchuk, 2016) outlines that in the present conditions of economic institutions CSR is a key element of a stable and sustainable development organizations, one of the effective mechanisms of investment attractiveness, competitiveness, loyalty and social strategies required component organizations are concerned about their reputation. The effect of CSR is most fully manifested in an increase in intangible assets; strengthening reputation; brand and image; increasing customer loyalty. Accordingly, the motivation to work increases, efficiency and productivity increases, and, as a result, the volume of services provided is increasing (Dyakiv, \& Demchuk, 2016).

The concern of the subject about its stakeholders (those affected by the results of its activities) indicates an expanded degree of social responsibility (Grishnova, Mishchuk, \& Oliynyk, 2014). Shastun (2016) proves the necessity of strengthening the responsibility of employers in fulfilling their obligations, as well as the expediency of consolidating in the labor legislation the principles of economic incentives for employers to ensure compliance with public and public interests.

Internal social responsibility - is, first of all, business practices with respect to its own staff, which should include the following activities (Dyakiv, 2015):

- timely selection and hiring professionals who have the necessary qualifications and personal qualities;

- motivation and stimulation of employees;

- social protection and health and social insurance of employees;

- evaluation of the results of work and personal qualities of staff;

- development of human capital of workers through various educational programs and training.

Internal social responsibility of the employer is a business practices on its own staff, which is the most important resource. The success of any organization depends on the availability of the required quantity and quality of staff at the right time and the right of selected positions that seek to meet their needs and the needs of the organization. Social responsibility in the field of employment includes: planning highly productive and qualitative composition of staff; organizing of recruitment; model assembly of workplace (requirements for future employee); mapping competencies, qualification card (a list of competencies for an applicant for the position); determine the sources of personnel attracting; the interview (questionnaires, tests, business games); selection of personnel; decision on hiring.

The employer must ensure non-discrimination in hiring practices, clear system of interaction with employees as key stakeholders. Social and labor relations between employer and employee should be aimed to ensure life quality, attract to enterprise qualified and talented employees.

Adaptation is one of the elements of the system of personnel management. Settling on a job applicant must quickly adapt to the demands of enterprise: regimes of work and rest, work rules, job descriptions, orders and instructions. He must accept the team which will work, tradition and philosophy of the organization to re-evaluate their capabilities, habits and attitudes. It is required a certain period of time that the employee became a full member.

Adaptation employee - is the process of joining the team, learning the rules and traditions that exist in the organization. It is required a certain time, so that the worker became an active member of the team and participated in its activities.

The adaptation to the post and the entry is aimed at ensuring the proper introduction to a function of the new employee, reducing possible errors related to his work, creating a positive image of the company, reducing dis- 
comfort in the first days of activities, and the evaluation of qualifications and potential employee during the passage of probation.

Adaptation program (plan entering) is designed for quick adaptation of new employees and their adaptation in all structural units of the organization. The program should develop and use in the heads of all departments.

The objective is to develop an overview of the organization, its main activities, organizational features, characteristics and relationships of the employee (the procedure of hiring, firing, pay, benefits, etc.), working conditions, and others.

This program is implemented during the first two weeks of the new employee. Some stages of the program used by the time the new design of the worker. First, you need to hold a tentative novice introductory interview.

The purpose of this procedure is to inform the new employee basic information about the organization, perspectives and features of the employment relationship between the organization and the employee.

Preliminary interview is conducted after the formulation of the final proposal on recruitment and agreement exit. After the paperwork in the department of personnel is presenting a new employee in the organization. It is conducted a direct acquaintance with the basic premises of the office and the department where new work specialist. All employees of the organization in the prescribed form receive information about a new employee. Last studies schematic structure of the organization, the hierarchy of positions, especially the work teams and groups acquainted with the basic principles of corporate culture.

Each organization must create entry plan to the job position.

Entry plan to position is determined by supervisor. Report on the passage of separate stages of the plan is provided to HR manager.

Entering the post provides more details on the specifics of the organization, especially the post and the specifics of the work, and gaining specific skills specific to a particular job.

This profile reflects a total office space functional and organizational system of the company. This means that the HR manager who follows the adaptation has to know who exactly how and what tasks involved in the adaptation of a new employee. Profile contains a clear description of duties professional and therefore should determine which functions the employee must be adapted.

The plan entering to job position covers the period of probation and covers two stages (direct entry to office and work on job position). For novice mentor is attached. Last supervisor appointed from among the most experienced staff. The task of the curator is to plan, conduct and evaluate the performance of a new employee during the period of his probation. The new employee must provide weekly reports curator work done under the individual plan. The coach evaluates his work and sends reports to supervisor and backup - manager staff.

- Supervisor conducts individual training a new employee in the following areas:

- study of the job description and requirements for the workplace; introduction of technology into a new job in a branch;

- receiving a package of documents that allow the new employee more comfortable and efficiently enter the organization;

- study the instructions on the technology's own works and works department (for example, study product range, customer service features, etc.);

- study of the instructions associated with the interaction of business units, and workflow rules.

This step involves entering a new employee to the position of full mastered their duties. 
At the end of the first month of the new employee record lets supervisor of the work done, the exam is based on the basic knowledge and skills. Management performs a preliminary analysis of employee performance and adjusts its activities.

The minimum required duties of personnel are productive employment, fair compensation policy, creating conditions for the full development of human potential, taking into account their own interests key business goals and strategies of the enterprise. The components of compensation policy include:

- monetary incentives (salary basic and additional, bonus, bonuses, allowances);

- non-monetary incentives (housing, car, place of treatment and rest, eating by the company, mobile phone payment, etc.);

- non-financial incentives (decent working conditions, safety, healthy psychological climate in the team);

- moral encouragement: respect, gratitude, diplomas, hall of fame, orders and medals, rank, etc.

The dominant feature of the implementation of social responsibility of employers in the area of compensation policy is stable and decent wages, development of social support staff (training package privileges and guarantees); catering, organization and payment of health care workers and their families, treatment, rest; health care workers; support for mothers and children; aid workers in emergency situations; financial aid; additional medical and social insurance of workers; good psychological climate in a team.

Personal and professional development is an important direction of positioning of the company as a socially responsible, essential condition for building social and labor relations between employers and employees on the principles of social responsibility and increase loyalty, motivation and responsibility of workers (Kolot, Grishnova, \& Gerasimenko et al., 2015).

Social responsibility in the field of training and staff development is: the education and training of employees; development of individual development plans for employees; choice of forms and methods of training employees; determining the effectiveness of training; service and professional advancement of workers; planning of career for employees, career management (move to higher positions); personnel reserve and others.

It is important to encourage employees to training at the workplace through the professional literature, professional periodicals subscription, order creative, more responsible and more complex challenges involving decision-making processes that go beyond the standard works (Kolot, \& Grishnova et al., 2012).

Staff development in the organization goes through training programs, professional development; training, internship; corporate universities; grants, research and practical development, the introduction of innovative employment through the "knowledge economy"; favorable conditions for the growth of the creative potential of employees.

The importance of staff evaluating is multistage, sequential process of studying of individual properties and (or) the results of activity of employee within HR. Assessment is a system process, elements of which are interrelated and interdependent by species, subjects, methods, indicators and so on.

Assessment of $\mathrm{HR}$ is a multistage, sequential process that includes:

- evaluation at hiring (evaluation of individual and professional qualities of the candidates: qualifications, experience, professional skills); evaluation in the selection of candidates (personal competences, professional, communication, psychological, cognitive);

- assessment of candidates for personnel staff reserve (education, skills, organizational skills, health, age, training);

- periodic assessment of the personal qualities of employees (professionalism, flexibility, adaptability, persistence in achieving goals, hard work, energy, stress);

- periodic evaluation of the results of employees (labor productivity, complexity of work, working conditions, 
the amount and quality of information received, the level of innovation;

- evaluation of employee motivation, self-motivation, self-fulfillment, key performance indicators (KPIs);

- evaluation of competencies (building of competencies model that includes - development - system competency for positions, choice of the most important experts in the degree of their importance, ranging competencies, determination of basic competencies and their evaluation criteria).

The important in HR is to develop criteria for evaluating socially responsible behavior of every employee in the system of evaluation of the results of work; assess competency; the efficacy of corporate social responsibility; attracting staff to corporate social programs; forming an internal communications system, which will inform all employees about strategy, plans, results and achievements in KSV.

\section{CONCLUSION. THE PROSPECTS FOR FURTHER RESEARCH}

Adhering to the principles of social responsibility, an organization maximize your score in the long run, on the one hand, motivates staff to comply with corporate social responsibility, and on the other - has a positive effect on society and the state in general.

\section{REFERENCES}

1. Belyayeva, I. Y., Eskindarov M. A. (Ed.) (2016). Корпоративная социальная ответственность [Korporativnaya sotsialnaya otvetstvennost] (320 p.). Moscow: KNORUS. Retrieved from http://static.my-shop.ru/product/pdf/203/2029663.pdf

2. Carroll, A. B. (1999). Corporate social responsibility: evolution of definitional construct. Business and society, 38(3), 268-295. https://doi.org/10.1177/000765039903800303

3. Dyakiv, O. P., Demchuk, N. (2016). Modern trends of corporate social responsibility. Rehionalni aspekty rozvytku produktyvnykh syl Ukrainy, 21, 67-70. Retrieved from http://rarrpsu.tneu.edu.ua/index.php/rarrpsu/article/view/187

4. Dyakiv, O. P., Demchuk, N. (2016). Система внутрішньої соціальної відповідальності організації [Systema vnutrishnoi sotsialnoi vidpovidalnosti orhanizatsii]. Economics and organization of management, 3(23), 164-171. Retrieved from http://jeou.donnu.edu.ua/ article/view/2884

5. Dyakiv, O. Р. (2015). Корпоративна соціальна відповідальність в стратегії управління персоналом [Кorporatyvna sotsialna vidpovidalnist v stratehii upravlinnia personalom] (223-234 pp.). In Hrynchutskyi V. (Ed.). Сучасні тенденції розвитку економічних систем [Suchasni tendentsii rozvytku ekonomichnykh system]. Ternopil: TNEU.

6. Grishnova, O. A., Mishchuk, G., Oliynyk O. (2014). Соціальна відповідальність у трудових відносинах: пеорія, практика, регулювання ризиків [Social responsibility in labor relations: theory, practice, risk management] (216 p.). Rivne: NUVGP. Retrieved from https://bitly.su/LokW0G

7. Grynenko, А. М. (2012). Корпоративна соціальна відповідальність: теоретико-методологічний аспект оцінювання соціальної діяльності [Korporatyvna sotsialna vidpovidalnist: teoretyko-metodolohichnyi aspekt otsiniuvannia sotsialnoi diialnosti]. Formuvannia rynkovoi ekonomiky Seriia: Pratsia v XXI stolitti, 58-68. Retrieved from http://ir.kneu.edu.ua/bitstream/2010/3611/1/58\%20 -\%2068.pdf

8. Kolot A. M., Grishnova A. et al. (2012). Соціальна відповідальність: теорія і практика розвитку [Sotsialna vidpovidalnist: teoriia i praktyka rozvytku] (501 p.). Kyiv: Kyiv national economic university. Retrieved from http://ir.kneu.edu.ua/handle/2010/11443

9. Kolot, A. M., Grishnova, O. A., Gerasimenko, O. O. et al. (Ed.) (2015). Соціальна відповідальність [Sotsialna vidpovidalnist] (519 p.). Kyiv: Kyiv national economic university. Retrieved from http://ir.kneu.edu.ua/bitstream/2010/11583/1/sotsial vidpovidal 15.pdf

10. Shastun, A. D. (2016). Забезпечення розвитку трудової сфери на засадах соціальної відповідальності [Zabеzресhеппіа rozvytku trudovoi sfery na zasadakh sotsialnoi vidpovidalnosti] (20 p.) (Extended abstract of Ph.D. thesis). Kyiv: Institute of industrial economics, National academy of sciences of Ukraine. 